\title{
Management of Inpres Market Traders in Banda Sakti District (Study of Disperidagkop Lhokseumawe City)
}

\author{
Mauludi ${ }^{1, *}$, Jumadil Saputra $^{2}$, Zikri Muhammad ${ }^{2}$, Alwi $^{3}$, Muryali ${ }^{1}$, Zuruh Zun \\ Natur $^{4}$, Muhammad Rizki Ikbal ${ }^{5}$ \\ ${ }^{1}$ Department of Public Administration, Faculty of Social and Political Sciences, Universitas \\ Malikussaleh, Lhokseumawe, Indonesia \\ ${ }^{2}$ Faculty of Business, Economics and Social Development (FBESD), UMT, Terengganu, Malaysia \\ ${ }^{3}$ Department of Sosiology, Faculty of Social and Political Sciences, Universitas Malikussaleh, \\ Lhokseumawe, Indonesia \\ ${ }^{4}$ Student of Law Faculty, Universitas Malikussaleh, Lhokseumawe, Indonesia \\ ${ }^{5}$ Student of Public Administration Department, Faculty of Social and Political Sciences, \\ Universitas Malikussaleh, Lhokseumawe, Indonesia
}

*Corresponding Author: Email: mauludi@unimal.ac.id

\begin{abstract}
Traders selling in the market emerge from an uneven condition of economic and educational development, besides that it is also the result of unavailability of jobs for small people who do not have the ability to produce. This problem has led to the Disperindagkop of Lhokseumawe city to make policies to manage and supervise traders. This study aims to determine how the management of the Presidential Market Traders in the city of lhokseumawe. This policy is a form of guidance for traders to occupy the stalls that have been provided. This type of research in this thesis is a descriptive study with a qualitative approach. The position of researchers in qualitative research is planning, implementing data collection, data analysis, data interpretation, and in the end become a reporter for the research results. So the researcher is the key research instrument. The types of data in this study are primary data and secondary data. The technique of collecting data by means of interviews, observation and documentation. Data analysis is guided by an interactive data analysis model. The results of this study are expected to be inputor donating thoughts and suggestions to local governments in managing market traders' stalls and improving the quality of market trading in their management The City Government in managing the Inpres market merchant stalls by the Disperindagkop of Lhokseumawe City is maximized. The need for direction, guidance, and control from the Disperindagkop against traders who do not comply with established rules can be given sanctions so that their implementation in the field can be fully implemented.
\end{abstract}

Keywords: Management, Traders

\section{INTRODUCTION}

In general, wet markets, often referred to as traditional markets, are seen as dirty areas, a source of traffic jams and a place of origin for criminals. This is based on or by factors of economic development which were initially only rooted in the problem of meeting the necessities of life (basic needs).

In traditional market activities there is interaction between sellers and buyers. There are three elements in the market, namely sellers, buyers and goods or services 
whose existence cannot be separated. The meeting between the seller and the buyer creates buying and selling transactions, but that does not mean that everyone who enters the market will buy goods, some come to the market just to play or want to meet someone to get information about something.

In line with the real evidence of the role of this traditional market in the government, it has shown an appreciation for its existence for traders and for the city or service area. It turns out that traditional markets have a strong capacity to survive in uncertain macroeconomic situations, and do not fall into a slump, such as formal economic activities or large-scale economic activities. The market has served as a rescue net and job provider for some communities.

This study will discuss one of the traditional markets in Lhokseumawe City, namely the Inpres Market. This inpres market is located in a strategic place, namely on Jalan Listrik in Lhokseumawe City, so this market is always crowded with people. This market is also a one-on-one market on the border between the villages of Kuta Blang, Tumpok Tengoh and the villages of Kampung Jawa Baru. In market activity there is an exchange of goods and services and the formation of prices.

The number of merchant stalls occupying the Presidential Market in Banda Sakti District, Lhokseumawe City, is as recorded in the table below:
Table 1.1

Details of 2015-2019 Inpres Market Traders in Lhokseumawe City

\begin{tabular}{|c|l|c|c|}
\hline No. & $\begin{array}{l}\text { Types of } \\
\text { Traders }\end{array}$ & Unit & Information \\
\hline 1 & $\begin{array}{l}\text { Little } \\
\text { merchant }\end{array}$ & $\begin{array}{c}342 \\
\text { Units }\end{array}$ & - \\
\hline 2 & $\begin{array}{l}\text { Micro } \\
\text { Traders }\end{array}$ & $\begin{array}{c}282 \\
\text { Units }\end{array}$ & - \\
\hline 3 & $\begin{array}{l}\text { Intermedi } \\
\text { ate } \\
\text { Trader }\end{array}$ & $\begin{array}{c}39 \\
\text { Units }\end{array}$ & - \\
\hline \multicolumn{2}{|l}{ amount } & 663 & \\
Units & \\
\hline
\end{tabular}

Source: Disperindagkop Lhokseumawe City Year 2019

The increase in traders in the inpres market in Lhokseumawe City could cause obstacles for market managers, namely Disperindagkop in placing traders who do not have stalls to trade, so that the opportunity for traders to have stalls that have been provided. Furthermore, to see the number of traders who occupy the Inpres market merchant stalls in Banda Sakti District, Lhokseumawe City in 2019, as shown in the table data below.

\section{Table 1.2}

Details of the Traders Occupying the Inpres Market Traders Lhokseumawe City in 2019

\begin{tabular}{|c|l|c|c|}
\hline No. & $\begin{array}{l}\text { Types of } \\
\text { Traders }\end{array}$ & Unit & Information \\
\hline 1 & $\begin{array}{l}\text { Little } \\
\text { merchant }\end{array}$ & $\begin{array}{c}147 \\
\text { Units }\end{array}$ & - \\
\hline 2 & $\begin{array}{l}\text { Micro } \\
\text { Traders }\end{array}$ & $\begin{array}{c}115 \\
\text { Units }\end{array}$ & - \\
\hline 3 & $\begin{array}{l}\text { Intermed } \\
\text { iate } \\
\end{array}$ & $\begin{array}{c}65 \\
\text { Units }\end{array}$ & - \\
\hline \multicolumn{2}{|c|}{ Trader } & 327 & \\
\hline
\end{tabular}

Source: Disperindagkop Lhokseumäwe City Year 2019

Based on empirical data, the researchers found that the number of merchant stalls in the presidential market in 2018 was not fully occupied by 327 units. Buyers who came to visit the Presidential Market 
came from various villages in Banda Sakti District and some came from Muara Dua District. From the explanation above, it can be concluded that the function of the market, especially traditional markets, is not only as a place for buying and selling transactions, but also as a medium of communication between villagers who live around the market. The market is a social media that connects communication between people in an area. In addition, the market is a location that provides employment for the community. No exception to the Presidential Market which has given birth to new jobs that are utilized by the community, such as pedicab or motorcycle taxi drivers, cart-pulling coolies, parking attendants, newspaper sellers and shoe-polishing workers. This indicates that the Presidential Market has an important role in reducing unemployment in the vicinity.

The location of the inpres market traders is very crowded, causing many traders' stalls or places to sell traders that are still not well organized and even do not follow the Regulation of the Minister of Trade

\begin{tabular}{|c|l|c|c|}
\hline No. & $\begin{array}{l}\text { Types of } \\
\text { Traders }\end{array}$ & Unit & Information \\
\hline 1 & $\begin{array}{l}\text { Little } \\
\text { merchant }\end{array}$ & $\begin{array}{c}147 \\
\text { Units }\end{array}$ & - \\
\hline 2 & $\begin{array}{l}\text { Micro } \\
\text { Traders }\end{array}$ & $\begin{array}{c}115 \\
\text { Units }\end{array}$ & - \\
\hline 3 & $\begin{array}{l}\text { Intermed } \\
\text { iate } \\
\text { Trader }\end{array}$ & $\begin{array}{c}65 \\
\text { Units }\end{array}$ & - \\
\hline \multicolumn{2}{|c|}{ amount } & $\begin{array}{c}327 \\
\text { Units }\end{array}$ & \\
\hline
\end{tabular}

of the Republic of Indonesia Number 70 / M-DAG / PER / 12/2013 concerning guidelines for structuring and fostering traditional markets, shopping centers, and a modern shop. As well as the Qanun of Lhokseumawe City Number 14 of 2012 regarding retribution for market services.

As for the background for conducting research related to the management of merchant stalls in the presidential market by the Disperidagkop of Lhokseumawe City, including:

1. There are still traders in the presidential market who trade in unofficial stalls (outside the stalls that have been provided).

2. The existence of illegal fees citing traders who do not sell in designated stalls.

3. The location of the merchant stalls is still not well ordered.

4. The management of the traders' stalls seems not yet appropriate

From the results of observations made by the author at the Inpres market in Lhokseumawe City, there are still many traders who sell on the side of the road and some even go to the road which is not a location for trading, resulting in traffic jams around the presidential market. In addition, there are still a lot of contribution quotes made by irresponsible people who are troubling the traders and there are still many stalls of traders in the Inpres market that are not yet orderly. (preliminary observation, 03 June 2020).

\section{RESEARCH METHODS}

\subsection{Research Design}

This research was designed through a qualitative approach This type of descriptive research is research that seeks to address 
existing problem solutions based on data.

The approach used in this research is a descriptive qualitative analysis approach, according to Sugiyono (2006: 11) is "a research approach used in data collection by examining problems that are happening at this time, then the data is collected and compiled, after which it is processed. and analyzed "With this design approach, it is hoped that accurate and reliable information will be extracted.

\subsection{Research Flowchart}

The research flow or roadmap for this research process can be described as follows:

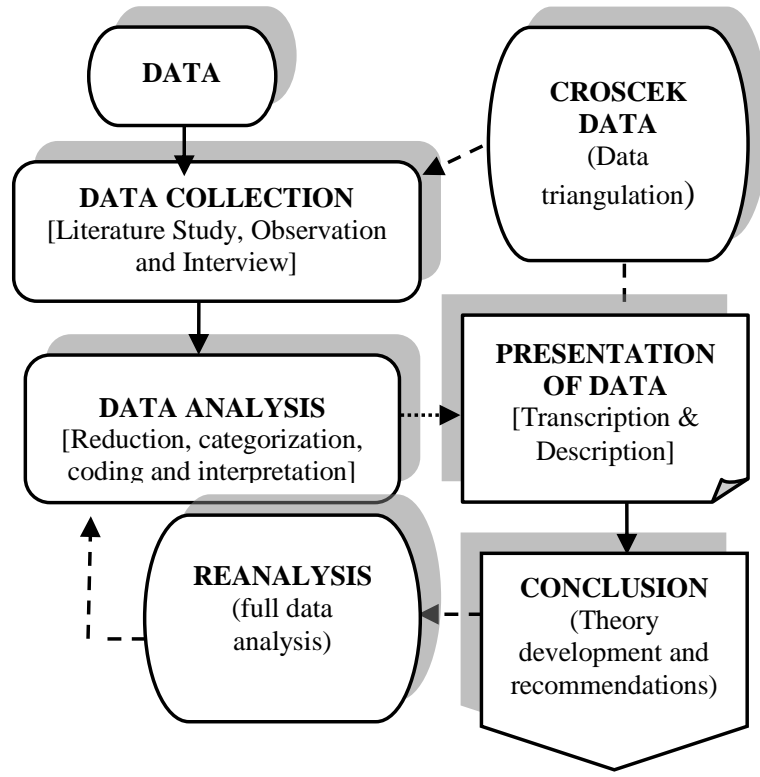

\subsection{Research Objects and Subjects}

The object of this research is an attribute of people, namely traders, stalls or markets and local government and society. The subjects of this study are called participants (informants / information providers from across professions) in the Lhokseumawe City community. The criteria for informants, among others; policy makers, heads of agencies, NGOs, traders, communities and others in the research area, are willing to be participants / informants and are willing to be interviewed.

\subsection{Data collection technique}

This study uses three data collection techniques, namely direct observation, passive involvement, in-depth interviews and documentation. Passive-involved direct observation is used to see directly the context of social reality, a description of individual altruistic behavior in various occasions holistically in social reality. Meanwhile, in-depth interviews are used to gather information related to the topic of study being studied.

Furthermore, documentation techniques are used to discuss the main ideas of this study in the context of naturalistic reality, namely according to the characteristics, habits, norms and cultural values that develop in the local community. Documentation can be in the form of theoretical concepts, results of previous studies, journal articles or other relevant information.

\subsection{Data analysis technique}

Analysis of the research data using the interaction model from Milles et al. (2014), namely:

1. Data reduction, namely collecting, organizing and coding the data obtained from reality.

2. Data presentation, namely the presentation of data on field findings in a comprehensive manner 
3. The conclusion of the data is that the researcher tries to analyze and interpret the data so that the meaning of each field finding data can be understood.

In addition, to cross-check data on field findings, either observation data, interviews or documentation, the researcher uses triangulation techniques as an effort to check the relevance and accuracy of the data, so that the reliability of the research data can be proven empirically.

\section{RESULTS AND DISCUSSION}

The results of the research that the researchers found in the field both in the form of observations, data collection and interviews from various figures above showed that the Lhokseumawe City Disperindagkop was still unable to manage the merchant stalls properly, there were still traders who had not waited for the regulations that had been set. Most of the traders still traded in trenches, in alleys and even on the side of the road which resulted in congestion and chaos in the Presidential Market.

The Disperindagkop of Lhokseumawe City has made every effort to solve the problems that occurred in the Presidential Market, given the behavior of traders who do not care about the rules that have been set. However, the Disperindagkop remains optimistic about socializing it to traders so that they can occupy the stalls provided by the government.

Based on empirical data, the researcher found that the number of merchant stalls in the presidential market in 2015 was approximately 327 units. But here the researcher saw that there were a number of traders who complained to the merchant stalls of the Disperindagkop that they provided 500 stalls of traders, but those who traded in the Inpres market were around 1000 traders. This has resulted in many traders selling on the side of the road, in alleys and even above ditches, causing various problems that occur in the presidential market, thus the Disperindagkop is obliged and must overcome this problem so that in the future there is no confusion in the market. Inpres.

Inpres market traders still complain a lot about the facilities and infrastructure provided by the Lhokseumawe City Industry and Trade Cooperative in providing services. The facilities that have been provided by Disperindagkop are still not being felt by the traders until now, such as inadequate merchant stalls. At least Disperindagkop provides lapak for traders who do not have a stall so that they do not trade in random places.

The Disperindagkop has regulated fees or taxes in accordance with the applicable regulations with a quote of 2000-5000 rupiah per stall according to the size of the stalls of the merchandise. Usually, those who quote fees or taxes are official officers, thus there is no fraud in the collection of fees or taxes.

Based on the results of the research, it seems that the first step taken by the Disperindagkop is to plan or socialize the traders carefully. This is very effective in dealing with all the problems that occur in the Inpres market. The number of traders 'stalls with traders is not appropriate, 
there are more traders than traders' stalls, proving that there is still a lot of work to be done by Disperindagkop and the government in overcoming this problem.

carried out can be planted with types of plants that are local species and facilitate the implementation of reclamation activities by maintaining the smoothness of the top soil.

\section{CONCLUSION}

From the discussion that the author has done, we cannot generalize that the problem of stalls for traders in the presidential market is just like what was discussed, but presumably this discussion can be a portrait for the Disperindagkop in supervising traders' stalls well so that the inpres market in Lhokseumawe City is always crowded with people. . From the discussion above, the following conclusions can be drawn:

1. Management of Inpres Market Traders By Disperindagkop Kota Lhokseumawe is still not optimal, so there is a need for increased supervision of the traders who occupy the stalls and there are no traders selling anywhere.

2. The factors that hinder the Management of Inpres Market Traders in Lhokseumawe City, namely the lack of facilities and infrastructure for traders who occupy the stalls that have been provided by the Department of Industry and Trade, so that traders can feel comfortable selling.
3. Unofficial citation of dues by irresponsible individuals causes traders to feel disadvantaged, so that the Disperindagkop must tighten supervision of those who carry out illegal quotations.

The suggestions that can be given are as follows:

1. The Kota Lhokseumawe Disperindagkop should coordinate with various parties related to stalls of traders in the Presidential Market so that traders who sell do not feel disadvantaged.

2. The Lhokseumawe City Disperindagkop should pay more attention to the traders in the presidential market and more fully supervise the traders so that traders can sell comfortably so that they do not sell in random places and the quotation of unofficial dues to traders can be avoided or disciplined. 


\section{AUTHOR CONTRIBUTION}

1. The results of this study are expected to contribute ideas to the general public and in particular to the management of the Presidential Market Traders in Lhokseumawe City.

2. As a scientific work that can be used as an initial study, so that it can be used as a follow-up study for those in need.

3. For the local government of Lhokseumawe City, Banda Sakti sub-district, and the Disperidagkop in particular it can be used as input to improve the Management of Inpres market traders so that it becomes better.

4. For the people of Lhokseumawe City and Banda Sakti sub-district and Disperindagkop in particular, it is hoped that they can participate more in the importance of the Management of Inpres Market Traders in Lhokseumawe City.

\section{REFERENCES}

Emzir. 2010. Qualitative Research Methodology for Data Analysis. Jakarta: PT. Raja Grafindo.

Moleong. 2010. Qualitative Research Methodology. Youth

Rosdakarya, Bandung.

Iskandar, 2009. Qualitative Research Methods. Jakarta: Echoes of Persada Press.

Puspitasari, Devi. 2007.

Entrepreneurship Planning
Micro / Macro Enterprises. Jakarta: CV Pandu Karya

Raharjo, Adisamita, 2011, Management of Regional Revenue and Budget. Graha Ilmu: Yogjakarta.

Rahman Saiful, 2012, basic-basic Management, Jakarta: Ghalia Indonesia.

Umar. 2008. Strategic Management in Action. Gramedia. Jakarta.

Salim Peter, Salim Yenny, 2012. Classroom and student management, Jakarta: CV. Eagle.

Shodikin, Utoyo, 2011. Marketing Management: Analysis, Planning and Control, Jakarta: Erlangga.

Soehartono, Irawan, 2008. Social Research Methods. Bandung: PT. Rosdakarya youth.

Terry, R, George and Leslie W, Rue, 2010. Fundamentals of Management, Indonesian edition, thirteenth printing. Jakarta: PT. Earth Literacy.

Hadari Nawawi. 2000. Human Resource Management. Ghalia Indonesia. Jakarta. 